\title{
ANATOMOPATHOLOGICAL ASPECTS OF NEUROCYSTICERCOSIS IN AUTOPSIED PATIENTS
}

\author{
Ruy de Souza Lino-Junior ${ }^{1}$, Ana Carolina Guimarães Faleiros², \\ Marina Clare Vinaud ${ }^{3}$, Flávia Aparecida de Oliveira', \\ Janaína Valadares Guimarães', Marlene Antônia dos Reis", \\ Vicente de Paula Antunes Teixeira ${ }^{4}$
}

\begin{abstract}
The aim of this paper was to describe the occurrence and morphology of neurocysticercosis (NCC) in autopsies. We revised 2218 autopsies performed at the School Hospital from Federal Unversity of Triangulo Mineiro, 1970-2003. Data referring to age, gender and color of patients were reported and NCC was microscopically and macroscopically analyzed. We found $53(2.4 \%)$ NCC cases. The mean age was 50 years old, $34(64.1 \%)$ individuals were male and 36 (67.9\%) white. Macroscopically, 17 cysticerci were analyzed. The most frequent location was meningocortical in $12(70.6 \%)$ cases. Microscopically, the cysticerci presented an ovoid shape, containing the larvae preserved in $4(23.5 \%)$ cases or in destruction degrees in $13(76.5 \%)$ cases. Therefore, in NCC was found several general pathologic processes (necrosis, interstitial deposits, fibrosis, gliosis, inflammation) amongst which are highlighted beta-fibrillose in 13 (76.5\%) cases associated to inflammatory process in $16(94.1 \%)$ cases caused by the parasite, not yet related to NCC, and calcification present in viable and destruction parasites.
\end{abstract}

KEY WORDS: autopsy neurocysticercosis, general pathologic processes, cysticercosis, central nervous system.

\begin{abstract}
Aspectos anatomopatológicos da neurocisticercose em pacientes autopsiados
RESUMO - O objetivo desse trabalho foi descrever ocorrência e morfologia da neurocisticercose (NCC) autópsias. Revisou-se 2218 autópsias realizadas no Hospital Escola da Universidade Federal do Triângulo Mineiro (UFTM), 1970-2003. Registrou-se idade, gênero e cor dos pacientes, analisou-se macroscopia e microscopia da NCC. Encontrou-se 53 (2,4\%) casos de NCC. A média das idades foi 50 anos, sendo $34(64,1 \%)$ do sexo masculino e 36 (67,9\%) brancos, não havendo diferença significante na comparação da idade, gênero e cor dos pacientes. Analisou-se macroscopicamente 17 cisticercos. A localização mais comum foi a meningocortical em $12(70,6 \%)$ casos. Microscopicamente, os cisticercos apresentaram forma oval contendo a larva íntegra em 4 (23,5\%) casos ou em grau de destruição em 13 (76,5\%) casos. Portanto, na NCC foram verificados vários processos patológicos gerais (necrose, depósitos intersticiais, fibrose, gliose, inflamação) destacando-se: beta-fibrilose em $13(76,5 \%)$ casos associada ao processo inflamatório em $16(94,1 \%)$ casos causado pelo parasito, ainda não relatada na NCC, e calcificação presente no parasito viável e em destruição.
\end{abstract}

PALAVRAS-CHAVE: autópsia, neurocisticercose, processos patológicos gerais, cisticercose, sistema nervoso central.

Human cysticercosis occurs due to ingestion, with contaminated food, of eggs containing oncospheres. In the intestinal portion the oncospheres hatch, penetrate in the intestinal wall and disseminate through blood and lymph vessels until it gets to several tissues, however with great tropism to the central nervous system (CNS) ${ }^{1,2}$. Neurocysticercosis (NCC) is char- acterized by presenting several clinic manifestations ${ }^{3}$. The polymorphism of its clinic manifestations depends not only on its localization but as well as on the number of parasites, on the developmental stages of cysticercus (viable or in destruction) and on the organic characteristic of the patient ${ }^{4}$.

$\mathrm{NCC}$ is the most frequent from of cysticercosis.

Study performed at the General Pathology Disciplines from Federal University of Triangulo Mineiro, Uberaba MG, Brazil (UFTM) and from Tropical Pathology and Public Health Institute from the Federal University of Goais, Goiânia GO, Brazil (IPTSP/UFG): ${ }^{1}$ Pathology Doctor, Professor at the General Pathology Discipline from IPTSP/UFG; 2Pathology Master, Professor at Cellular Biology Discipline from UFTM; ${ }^{3}$ Tropical Medicine Master, doctorate student from the Tropical Medicine Post-Graduation Programme from IPTSP/UFG; " Pathology Doctor and Professor at the General Pathology Discipline from UFTM. Financial support: Conselho Nacional de Desenvolvimento Científico e Tecnológico (CNPq), Fundação de Amparo à Pesquisa do Estado de Minas Gerais (FAPEMIG), Fundação de Ensino e Pesquisa de Uberaba (FUNEPU).

Received 20 July 2006, received in final form 3 October 2006. Accepted 26 October 2006.

Dr. Ruy de Souza Lino Junior - Universidade Federal de Goiás / Instituto de Patologia Tropical e Saúde Pública I Disciplina de Patologia Geral - Rua 235 esquina com $1^{a}$ Avenida S/N / Setor Universitário - 74605-050 Goiânia GO - Brasil. E-mail: ruy@iptsp.ufg.br 
The frequency of NCC in autopsies in Brazil varies from 0.12 to $19 \%$, in clinic manifestations varies from 0.03 to $7.5 \%$ and in serum-epidemiologic studies from 0.68 to $5.2 \%$. The areas with high frequency reports of this disease are: São Paulo, Rio de Janeiro, Parana, Minas Gerais, Espirito Santo, Bahia, Rio Grande do Norte, Paraiba and Distrito Federal. The age bracket prevails between 21 to 40 years old. The male gender is the most common and the rural area precedence prevails. The predominant clinic manifestation is epilepsy followed by intracranial hypertension ${ }^{5-13}$. Cysticerci may be found in an active form causing arachnoiditis, hydrocephaly by meningeal inflammation, parenchymatous cysts and cerebral infarct; or in an inactive form that can be constituted by parenchymatous calcifications. The most common signs and symptoms of NCC are epilepsy, cephalalgia, papilledema, vomit and pyramidal signs ${ }^{14-19}$. Accordingly to Takayanagui and Leite ${ }^{20}$, in a review article, the frequency of these manifestations are: epileptic crisis $(62 \%)$, intracranial hypertension syndrome $(38 \%)$, cysticercotic meningitis (35\%), psychic disturbance $(11 \%)$, apoplectic or endarteritic form (2.8\%) and spinal cord syndrome $(0.5 \%)$. The lacunar cerebral infarct, which is one of the NCC cerebrovascular complications, results from the arterial occlusion secondary to intense inflammatory reaction. The arachnoiditis due to NCC is in many cases associated to hydrocephaly ${ }^{14,15}$.

The aims of this study were to describe the frequency and the anatomopathological aspects of NCC in autopsied individuals.

\section{METHOD}

Autopsy protocols performed at the School Hospital from Federal University of Triangulo Mineiro (UFTM), Uberaba, Minas Gerais, were revised from 1970 to 2003. From individuals with or without cysticercosis were reported: age, color, gender and localization of the cysticerci in the encephala. After approval of the Ethics in Research Committee from UFTM, macroscopic and microscopic analysis were performed of the lesions associated to cysticerci in the encephala recovered from anatomic organs archive at the General Pathology Discpiline, UFTM. Macroscopically, were evaluated the number of cysticerci in each organ, the implantation site of the cysticercus and the general pathologic processes (GPP). To the microscopic analysis, the encephalic fragments with cysticercosis were submitted to routine processing followed by cutting of $6 \mu \mathrm{m}$ width sections. These sections were stained by hematoxylin-eosin (HE) technique, or histochemical techniques when necessary such as Sirius red, to fibrosis identification, periodic acid-Schiff (PAS), to glicidic radicals deposits identification, von Kossa, to calcium salts deposits identification, Congo red, to betafibrilosis and Giemsa accordingly to established techniques ${ }^{21}$.
The microscopic analysis was performed aiming the identification of GPP that could occur in three distinguished sites: at the parasite, at the host-parasite interface and at the host tissue.

To the statistical analysis an electronic sheet was elaborated. Afterwards the variable were tested to verify the normal distribution and variance through KolmogorovSmirnov test. When the distribution was normal, parametric tests were used: in the comparison of two groups the " $t$ " Student's test and in the comparison of three or more groups the variance analysis for multiple groups. When the distribution was not normal, non parametric tests were used: in two groups comparison the Mann-Whitney test and in the three groups comparison the Kruskal-Wallis test. The proportions were compared by the $\chi^{2}$ test followed by the exact Fisher test. Statistically significant differences were considered when $p<0.05$

\section{RESULTS}

2218 autopsies protocols were revised and 71 (3.2\%) cysticercosis reports were found. From these cases, $53(74.6 \%)$ presented NCC representing $2.4 \%$ from the total number of autopsies. The mean of age was 50 years old, varying from 21 to 70 years old in NCC individuals: from 21 to 30 years old, 1 NCC case; from 31 to 40 years old, no NCC case; from 41 to 50 years old, 4 NCC cases; from 51 to 60 years old, 3 NCC cases and from 61 to 70 years old, 2 NCC cases. The mean of age of individuals without NCC was 48 years old varying from 15 to 99 years old. From the NCC individuals $34(64.1 \%)$ were male and $36(67.9 \%)$ were white. There were no statistically significant differences in the age, gender and color comparisons between patients ( $p>0.05$ ).

From the 53 patients with NCC it was possible to recover 10 encephala and the greater number of cysticerci found in one encephala was five. The macroscopic analysis was made in 17 cysticerci. The most common localization was meningocortical with 12 $(70.6 \%)$ cases, followed by interventricular with 2 $(11.7 \%)$ cases, hypothalamic with $2(11.7 \%)$ cases and white matter with $1(6 \%)$ case. In the host tissue it was most frequently found the focal leptomeningitis because the cysticerci were causing compression and subsequent deformation of the nearby tissue.

In the microscopic analysis of the 17 cysticerci, they usually presented an ovoid shape containing a viable larvae in $4(23.5 \%)$ cases or in varied degrees of destruction in $13(76.5 \%)$ cases. The GPP found were necrosis, deposit of glicidic radicals (Fig 1), betafibrillose (Fig 2), fibrosis (Fig 3), gliosis, calcification and hemosiderosis (Table). The inflammation reaction was identified with lymphocyte and monocyte prevailing and, eventually, with some giant cells, even 


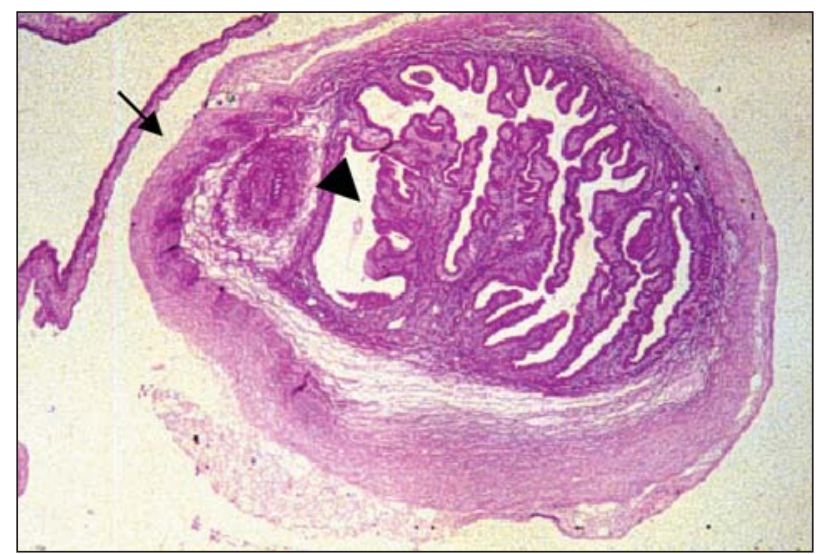

Fig 1. Viable cysticercus in meningocortical localization. Glicidic radicals deposits are observed, as well as PAS positive, in the duct area (arrow head) and membranes (arrow) of the parasite (periodic acid-Schiff, 50X).

so it was possible to identify eosinophils and mastocytes. It was also found hyperemia, specially on host tissue vessels, in $23.5 \%$ of cases; thickening of vessel walls exclusively on host tissue in $35.5 \%$ of cases; edema in host tissue in $100 \%$ of cases; hypotrophy in host tissue in $5.9 \%$ of cases; cellular growth and differentiation alterations in the host-parasite interface in $5.9 \%$ of cases presented as increase of cellularity of glia cells, discrete cellular pleomorphism with little variation on the distribution and quantity of chromatin accompanied by mild vascular proliferation. There was no statistically significant difference between the GPP and the localization of the cysticerci in the encephala.

\section{DISCUSSION}

In this study an occurrence of $2.4 \%$ of NCC was found in autopsies, this is in accordance with values described also in autopsy material that varies from

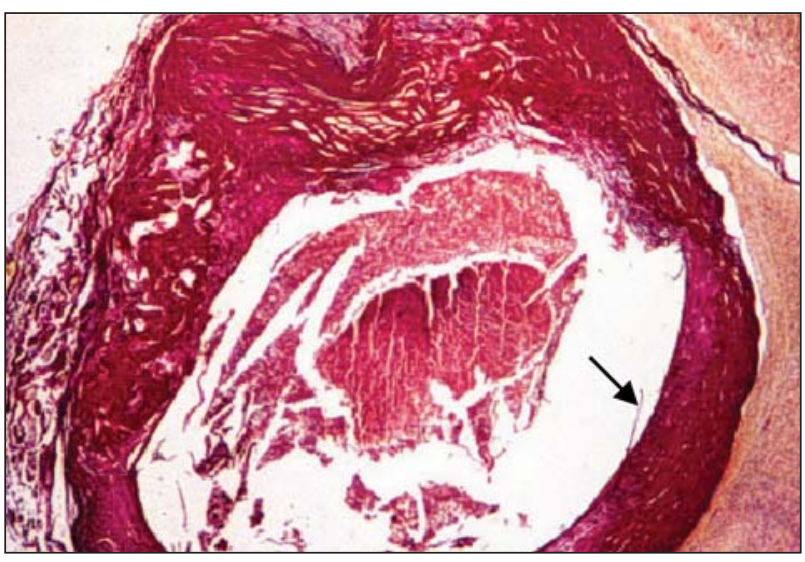

Fig 2. Cysticercus in destruction in meningocortical localization. Fibrous connective tissue (arrow) neoformation is observed in the parasite, in the host-parasite interface and in the host tissue (Picro red, 50X).

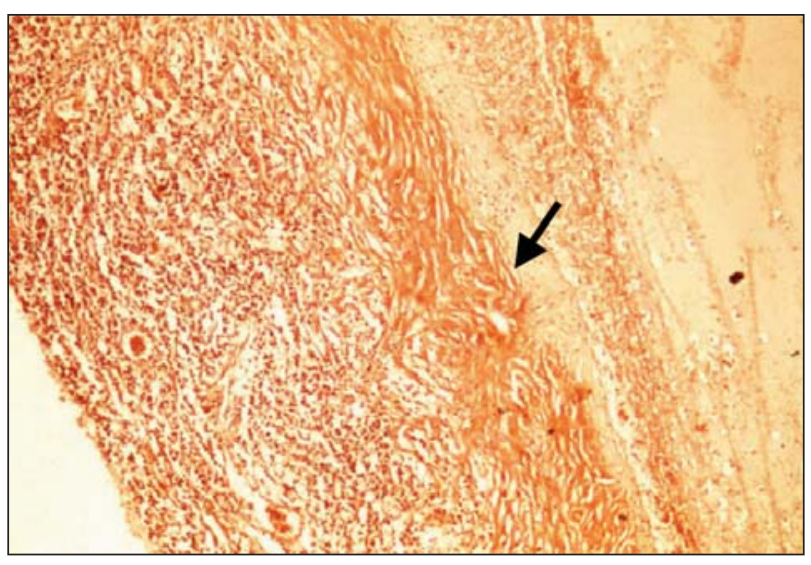

Fig 3. Host-parasite interface nearby a cysticercus in destruction in meningocortical localization. Beta-fibrils deposits (amiloidosis) (arrow) are observed (Congo red, 125X).

$0.12 \%$ to $9 \%$. The patients mean age in this study was 50 years old which represents a higher age bracket when compared to the one described in a review

Table. Distribution of general pathologic processes found in 17 cysticerci from autopsied individuals at the School Hospital of the Federal University of Triangulo Mineiro, Uberaba (MG), in the period from 1970 to 2003, accordingly to committed site.

\begin{tabular}{lcccc}
\hline Sites & \multicolumn{2}{c}{ Parasite } & Host-parasite interface & Host \\
\cline { 2 - 3 } Pathologic processes & Viable $\mathrm{n}(\%)$ & In destruction $\mathrm{n}(\%)$ & $\mathrm{n}(\%)$ & $\mathrm{n}(\%)$ \\
\hline Cell death & - & $1(5.9)$ & $1(5.9)$ & $5(29.4)$ \\
Glicidid radical deposits & $2(11.8)$ & $9(52.9)$ & $11(64.7)$ & - \\
Beta-fibrillose & - & $2(11.8)$ & $13(76.5)$ & $1(5.9)$ \\
Gliosis & $2(11.8)$ & $4(23.5)$ & $16(94.1)$ & $16(94.1)$ \\
Calcification & $1(5.9)$ & $5(29.4)$ & $3(17.6)$ & $1(5.9)$ \\
Hemosiderosis & - & $4(23.5)$ & $3(17.6)$ & - \\
Inflammation & $1(5.9)$ & $4(23.5)$ & $16(94.1)$ & $14(82.4)$ \\
Vascular proliferation & - & - & $15(88.2)$ & $13(76.5)$ \\
\hline
\end{tabular}

Observation: The sum is higher than $100 \%$ because the pathologic processes were found in more than one localization. 
article varying from 21 to 40 years old ${ }^{12}$. Maybe this difference can be explained because this review article gathered clinic, serum-epidemiologic and autopsies data while we only considered autopsies data. Overall the white NCC individuals prevailed in comparison to the non-white ones, which is compatible to other authors' data ${ }^{12,23}$. Furthermore, the male gender was more frequent than the female one accordingly to the reported literature ${ }^{24}$.

The organism reaction surrounding the cysticercus may occur accordingly to its localization in several organs as well as in the same organ the lesions can vary accordingly to its implantation site. The meningocortical localization of encephala cysticerci is highlighted because it causes more severe lesions while inside the parenchyma more discrete lesions were observed. Differently from the data described by Chimelli et al..$^{25}$ reporting the parenchymatous localization as the most frequent in NCC.

The inflammatory infiltrate of mononuclear cells in the cystic wall, the gliosis, the tissue edema and the thickening of small vessels near to the cysticerci were discrete in viable cysticerci. While the host's inflammatory response became more intense the parasite began to suffer a destruction process that resulted in its death. With the parasite's disintegration the inflammatory reaction tended to decrease although the persistence of giant cells surrounded by the fibrous capsule, gliosis and edema. According to the literature this fact indicates a continuum of the host's reaction against the parasite's debris without, however, an association to the type or intensity of the inflammatory response ${ }^{22}$.

The necrosis of neurons near the cysticercus implantation site is probably due to the compression caused by the parasite or by the secretion of mediators from the cysticercus or by the inflammatory response in the nearby tissue which is in accordance to other studies ${ }^{26}$.

Glicidic radicals' deposits were observed in the parasite and in the host-parasite interface. Accordingly to Thomas et al. ${ }^{27}$ these deposits inside intraparasitary vacuoles are connected to the parasite's metabolism. Therefore there is a relation to the viability of the cysticercus such as the greater number of intraparasitary vacuoles the more viable is the parasite. Besides these gathering indicates a probable crossed reactivity with the embryonic tissue that composes the larvae ${ }^{28}$.

In this study, the beta-fibrillose most frequent site was the host-parasite interface which corresponds to the main inflammatory site. However, in the literature there are no reports found related to beta-fibrillose associated to cysticercosis. Accordingly to some authors this type of deposit in other diseases occurs due to complications of a chronic inflammatory process or of a process that destroys the tissue and, therefore, being called secondary beta-fibrillose ${ }^{29}$. The association of beta-fibrillose to the inflammatory process may be due to the presence of precursor of the serum $A$ amyloidal substance (SAA) which have several immunomodulatories attributions such as chemotaxis induction and the expression of adhesion molecules besides the cytokine like proprieties. The SAA acts through some mechanisms in the lesion sites aiming the repair of the tissue. The increase and consequent deposit of these substance products are the process we call beta-fibrillose ${ }^{30}$.

The calcification was identified more frequently in cysticerci in destruction stage, however we also observed calcification in viable cysticerci and with discrete intensity. Accordingly to other studies that describe the calcification as an important process in $\mathrm{NCC}^{31}$, specially in more advanced evolutive stages and representing the most important finding in computerized tomography diagnosis ${ }^{26}$. Accordingly to Vargas-Parada et al. ${ }^{31}$ the calcification found in viable cysticerci may be explained by the calcareous corpuscles produced by the parasite and deposited in the lumen of protonephridial ducts.

The lesions in the growth and cellular diferentiation were identified in the host-parasite interface in one NCC case and is in accordance to the literatu$\mathrm{re}^{32}$ which indicates a significant association between $\mathrm{NCC}$ and gliomas.

In conclusion, in NCC were found several pathologic processes that differ in localization, cysticercus viability, aggression mechanism and immunologic response, besides its intensity is varied accordingly to three distinguished sites: the parasite, the hostparasite interface and the host's tissue. Beta-fibrillose associated to the inflammatory process caused by the parasite is highlighted and have not yet been described related to cysticercosis. The calcification is seen differently from the description of other authors revealing the possibility of a pattern that may result in a greater NCC diagnosis difficulty.

Aknowledgments - The authors thank Lorena Dourado Alves, Juliana Sayuri Sugita and Amélia Regina Semerene Farah for the support in this study. 


\section{REFERENCES}

1. Del Brutto OH, Sotelo J. Neurocysticercosis: an update. Rev Infect Dis 1988;10:1075-1087.

2. Flisser A. Taeniasis-cysticercosis: an introdution. Southeast Asian J Trop Med Public Health 1991;22:233-235.

3. Pedretti L, Bedaque EA, Sotelo J, Del Brutto OH. Cisticercose. In Veronesi R, Focaccia R (Eds). Tratado de infectologia, 2.reimpressão. São Paulo: Editora Atheneu, 1999:1332-1347.

4. Nascimento E. Teníase e cisticercose. In Neves DP (Ed). Parasitologia humana. 9.Ed. São Paulo: Editora Atheneu, 1998:244-256.

5. Gobbi H, Adad SJ, Neves RR, Almeida HO. Ocorrência de cisticercose (Cysticercus cellulosae) em pacientes necropsiados em Uberaba, MG. Rev Patol Trop 1980;9:51-59.

6. Peregrino AJP, Porto SO. Neurocisticercose no sudeste da Bahia. Arq Neuropsiquiatr 1985;43:55-60.

7. Costa-Cruz JM, Rocha A, Silva AM, et al. Ocorrência de cisticercose em necropsias realizadas em Uberlândia, Minas Gerais, Brasil. Arq Neuropsiquiatr 1995;53:227-232

8. Albuquerque ES, Galhardo I. Neurocisticercose no Estado do Rio Grande do Norte. Arq Neuropsiquiatr 1995;53:464-470.

9. Takayanagui OM, Castro E, Silva AAMC, et al. Notificação compulsória da cisticercose em Ribeirão Preto - SP. Arq Neuropsiquiatr 1996; 54:557-564.

10. Gonçalves-Coelho TD, Coelho MDG. Cerebral cysticercosis in Campina Grande, Paraíba - northern Brazil. Arq Neuropsiquiatr 1996;54:94-97.

11. Gomes I, Veiga M, Embiruçu EK, et al. Taeniasis and cysticercosis prevalence in a small village from northeastern Brazil. Arq Neuropsiquiatr 2002;60:219-223.

12. Agapejev S. Aspectos clínicos-epidemiológicos da neurocisticercose no Brasil: análise crítica. Arq Neuropsiquiatr 2003;61:822-828.

13. Lino-Junior RS, Reis MA, Teixeira VPA. Ocorrência de cisticercose (Cysticercus cellulosae) encefálica e cardíaca em necropsias. Rev Saúde Publ 1999;33:60-63.

14. Queiroz AC, Martinez AMB. Envolvimento do sistema nervoso central na cisticercose. Arq Neuropsiquiatr 1979;37:34-41.

15. Rubio-Donnadieu F. Aspectos clínicos de la neurocisticercose. Gac Med Mex 1988;124:194-197.

16. Silva $\mathrm{AV}$, Martins $\mathrm{HH}$, Marques $\mathrm{CM}$, et al. Neurocysticercosis and micro- scopic hippocampal dysplasia in a patient with refractory mesial temporal lobe epilepsy. Arq Neuropsiquiatr 2006;64:309-313.

17. Trentin AP, Teive HAG. Achados tomográficos em 1000 pacientes consecutivos com antecedentes de crises epilépticas. Arq Neuropsiquiatr 2002;60:416-419.

18. Rocha MSG, Brucki SMD, Ferraz AC, Piccolo AC. Doença cerebrovascular e neurocisticercose. Arq Neuropsiquiatr 2001;59:778-783.

19. Takayanagui OM. Neurocisticercose: II. Avaliação da terapêutica com praziquantel. Arq Neuropsiquiatr 1990;48:11-15.

20. Takayanagui OM, Leite JP. Neurocisticercose. Rev Soc Bras Med Trop 2001;34:283-290.

21. Prophet EB, Mills B, Arrington JB, Sobin LH. Laboratory methods in histotechnology. Amer Registry Pathol, Washington 1994:278.

22. Agapejev S. Epidemiology of neurocysticercosis in Brazil. Rev Inst Med Trop São Paulo 1996;38:207-216.

23. Spina-França A, Livramento JA, Machado LR. Cysticercosis of the central nervous system and cerebrospinal fluid. Arq Neuropsiquiatr 1993; 51:16-20.

24. Montemor MR Netto, Gaspareto EL, Faoro LN, et al. Neurocisticercose. Arq Neuropsiquiatr 2000;58:883-889.

25. Chimelli L, Lovalho AF, Takayanagui OM. Neurocisticercose: contribuição da necropsia na consolidação da notificação compulsória em Ribeirão Preto-SP. Arq Neuropsiquiatr 1998;56:577-584.

26. Pittella JEH. Neurocysticercosis. Brain Pathol 1997;4:681-693.

27. Thomas JA, Kothare SN, Baptist SJ. Cysticercus cellulosae. J Trop Med Hyg 1973;76:106-110.

28. Thomas JA, Knoth R, Schwechheimer K, et al. Disseminated human neurocysticercosis. Acta Neuropathol 1989;78:594-604.

29. Cotran RS, Kumar V, Robbins SL, et al. Doenças da imunidade. In Cotran RS, Kumar V, Robbins SL, et al (Eds). Patologia estrutural e funcional. 6.Ed. Rio de Janeiro: Editora Guanabara Koogan, 2000:152-212.

30. Cunnane G, Whitehead, AS. Amyloide precursors and amyloidosis in rhelmatoid arthritis. Baillieres Best Pract Res Clin Rheumatol 1999; 13:615-28.

31. Vargas-Parada L, Merchant MT, Willms K, et al. Formation of calcareous corpuscles in the lumen of excretory canals of Taenia solium cysticerci. Parasitol Res 1999;85:88-92.

32. Del Brutto $\mathrm{OH}$, Castillo PR, Mena IX, et al. Neurocysticercosis among patients with cerebral gliomas. Arch Neurol 1997;54:1125-1128. 